\title{
A Density Functional Theory Investigation on Intramolecular Hydrogen Transfer of the $\left[\mathrm{Os}_{3}(\mathrm{CO})_{11} \mathrm{P}(\mathrm{OMe})_{3}\left(\mathrm{Ru}\left(\eta^{5}-\mathrm{C}_{5} \mathrm{H}_{5}\right)\right)_{2}\right]$ Cluster
}

\author{
Radchada Buntem, ${ }^{*}$ Kraiwan Punyain, ${ }^{\dagger}$ Yuthana Tantirungrotechai, ${ }^{\ddagger, *}$ Paul R. Raithby, ${ }^{\S}$ and Jack Lewis ${ }^{\#}$ \\ Department of Chemistry, Faculty of Science, Silpakorn University, Nakorn Pathom 73000, Thailand \\ *E-mail: radchadab@yahoo.com \\ ${ }^{\dagger}$ Department of Chemistry, Faculty of Science, Naresuan University, Phitsanulok 65000, Thailand \\ ${ }^{\ddagger}$ National Nanotechnology Center (NANOTEC), National Science and Technology Development Agency, \\ Pathumthani 12120, Thailand.*E-mail: yuthana@nanotec.or.th \\ ${ }^{\S}$ Department of Chemistry, University of Bath, Bath BA2 7AY, United Kingdom \\ "Department of Chemistry, University of Cambridge, Cambridge CB2 1EW, United Kingdom \\ Received September 14, 2009, Accepted February 17, 2010
}

\begin{abstract}
The reduction of $\left[\mathrm{Os}_{3}(\mathrm{CO})_{11} \mathrm{P}(\mathrm{OMe})_{3}\right]$ and subsequent ionic coupling of the reduced species with $\left[\mathrm{Ru}\left(\eta^{5}-\mathrm{C}_{5} \mathrm{H}_{5}\right)\right.$ $\left.\left(\mathrm{CH}_{3} \mathrm{CN}\right)_{3}\right]^{+}$resulted in the formation of $\left[\mathrm{Os}_{3}(\mathrm{CO})_{11} \mathrm{P}(\mathrm{OMe})_{3}\left(\mathrm{Ru}\left(\eta^{5}-\mathrm{C}_{5} \mathrm{H}_{5}\right)\right)_{2}\right]$ which can be converted to spiked tetrahedral cluster, $\left[\mathrm{HOs}_{3}(\mathrm{CO})_{11} \mathrm{P}(\mathrm{OMe})_{3} \mathrm{Ru}_{2}\left(\eta^{5}-\mathrm{C}_{5} \mathrm{H}_{5}\right)\left(\mathrm{C}_{5} \mathrm{H}_{4}\right)\right]$ via the intramolecular hydrogen transfer. Due to the unavailability of a suitable single crystal, the PW91/SDD and LDA/SDD density functional methods were used to predict possible structures and the available spectroscopic information (IR, NMR) of $\left[\mathrm{Os}_{3}(\mathrm{CO})_{11} \mathrm{P}(\mathrm{OMe})_{3}\left(\mathrm{Ru}\left(\eta^{5}-\right.\right.\right.$ $\left.\left.\mathrm{C}_{5} \mathrm{H}_{5}\right)\right)_{2}$ ]. The most probable geometry found by constrained search is the isomer (a2) in which the phosphite, $\mathrm{P}(\mathrm{OMe})_{3}$, occupies an axial position on one of the two osmium atoms that is edge bridged by the $\mathrm{Ru}(\mathrm{CO})_{2}\left(\eta^{5}-\mathrm{C}_{5} \mathrm{H}_{5}\right)$ unit. By using the most probably geometry, the predicted infrared frequencies and ${ }^{1} \mathrm{H},{ }^{13} \mathrm{C}$ and ${ }^{31} \mathrm{P} \mathrm{NMR}$ chemical shifts of the compound are in the same range as the experimental values. For this type of complex, the LDA/SDD method is appropriate for IR predictions whereas the OPBE/IGLO-II method is appropriate for NMR predictions. The activation energy and reaction energy of the intramolecular hydrogen transfer coupled with the structural change of the transition metal framework were estimated at the PW91/SDD level to be 110.32 and $-0.14 \mathrm{kcal} / \mathrm{mol} \mathrm{respectively}$.
\end{abstract}

Key Words: DFT, Osmium-carbonyl cluster, Intramolecular hydrogen transfer

\section{Introduction}

A transition metal cluster is a collection of bound transition metal atoms that exhibits distinguish physico-chemical properties from those of bulk or isolated atoms. ${ }^{1}$ It can exist in various forms and nuclearities depending on its composition, stability and the synthetic pathway. Research in transition-metal cluster is now in focus again due to the recent interest in nanostructured materials for a much wider range of practical applications, including catalysis. ${ }^{2-4}$ Building large carbonyl clusters and exploring their physico-chemical properties has long been an active research area for many synthetic inorganic chemists including our research on building a transition metal cluster with mixed metal atoms with high nuclearity. ${ }^{5-8}$

An efficient pathway to build nuclearity clusters is the reduction of the parent cluster with subsequent ionic coupling between the parent cluster anion and a suitable cationic capping complex. The cationic capping species such as $\mathrm{Ru}\left(\eta^{5}-\mathrm{C}_{5} \mathrm{H}_{5}\right)$ $\left.\left(\mathrm{CH}_{3} \mathrm{CN}\right)_{3}\right]^{2+9},\left[\mathrm{Ru}\left(\eta_{5}^{6}-\mathrm{C}_{6} \mathrm{H}_{6}\right)\left(\mathrm{CH}_{3} \mathrm{CN}\right)_{3}\right]^{2+10}\left[\mathrm{Os}\left(\eta^{6}-\mathrm{C}_{6} \mathrm{H}_{6}\right)\left(\mathrm{CH}_{3}\right.\right.$ $\left.\mathrm{CN})_{3}\right]^{2+11}$ and $\left[\mathrm{Ru}\left(\eta^{5}-\mathrm{C}_{5} \mathrm{H}_{5}\right)\left(\mathrm{CH}_{3} \mathrm{CN}\right)_{3}\right]^{+},{ }_{12}$ which are isolobal to the $\left[\mathrm{M}(\mathrm{CO})_{3}\right]$ fragment, ${ }^{13}$ have been reacted effectively with anionic cluster compounds to build the higher nuclearity clusters. The reaction between $\left[\mathrm{Os}_{3}(\mathrm{CO})_{11} \mathrm{P}(\mathrm{OMe})_{3}\right]^{2-}$ with $\left[\mathrm{Ru}\left(\eta^{5}-\mathrm{C}_{5} \mathrm{H}_{5}\right)\right.$ $\left.\left(\mathrm{CH}_{3} \mathrm{CN}\right)_{3}\right]^{+}$resulted in the formation of $\left[\mathrm{Os}_{3}(\mathrm{CO})_{11} \mathrm{P}(\mathrm{OMe})_{3}\right.$ $\left.\left(\mathrm{Ru}\left(\eta^{5}-\mathrm{C}_{5} \mathrm{H}_{5}\right)\right)_{2}\right] .{ }^{8}$ By using the empirical 18 electron rule, the structure of $\left[\mathrm{Os}_{3}(\mathrm{CO})_{11} \mathrm{P}(\mathrm{OMe})_{3}\left(\mathrm{Ru}\left(\eta^{5}-\mathrm{C}_{5} \mathrm{H}_{5}\right)\right)_{2}\right]$ was predicted to be square-base pyramidal from the total electron count of
74. But there exists many possible isomers due to several threedimensional atomic arrangements in this structure. This compound underwent intramolecular hydrogen transfer upon heating in toluene under reflux condition to yield $\left[\mathrm{HOs}_{3}(\mathrm{CO})_{11}\right.$ $\left.\mathrm{P}(\mathrm{OMe})_{3} \mathrm{Ru}_{2}\left(\eta^{5}-\mathrm{C}_{5} \mathrm{H}_{5}\right)\left(\mathrm{C}_{5} \mathrm{H}_{4}\right)\right]^{8,14}$ Although spectroscopic characterizations (MS, IR and NMR) were carried out on $\left[\mathrm{Os}_{3}(\mathrm{CO})_{11}\right.$ $\left.\mathrm{P}(\mathrm{OMe})_{3}\left(\mathrm{Ru}\left(\eta^{5}-\mathrm{C}_{5} \mathrm{H}_{5}\right)\right)_{2}\right]$ and $\left[\mathrm{HOs}_{3}(\mathrm{CO})_{11} \mathrm{P}(\mathrm{OMe})_{3} \mathrm{Ru}_{2}\left(\eta^{5}-\right.\right.$ $\left.\mathrm{C}_{5} \mathrm{H}_{5}\right)\left(\mathrm{C}_{5} \mathrm{H}_{4}\right)$ ] to determine their structures, the unavailability of suitable single crystal of $\left[\mathrm{Os}_{3}(\mathrm{CO})_{11} \mathrm{P}(\mathrm{OMe})_{3}\left(\mathrm{Ru}\left(\eta^{5}-\mathrm{C}_{5} \mathrm{H}_{5}\right)\right)_{2}\right]$ for an X-ray diffraction experiment makes the other structural determination less conclusive. We chose to investigate possible geometries of these complexes by using computational techniques. The spectroscopic parameters were calculated and compared with available experimental data to validate our predicted structures.

Nowadays computational techniques have gained wider acceptance as a useful complementary tool to experimental techniques. The Density Functional Theory (DFT) method is now a method of choice for electronic structure calculation due to its accuracy at low computational cost. By specifying the exchange-correlation functional, the DFT method takes into account the electron correlation, which is crucial for transition metal complexes, while keeping the computational cost as low as that of the Hartree-Fock method. ${ }^{15}$ Common exchange-correlation functionals are the local density approximation (LDA), Perdew-Wang gradient corrected functional (PW91) and Becke's three parameters hybrid functional (B3LYP). Many literatures 
use DFT calculations to help elucidating the geometry and spectroscopic information. ${ }^{3,16-18}$

Maruo et al. synthesized tricarbonyl rhenium complexes by several synthetic pathways. ${ }^{3}$ Three complexes were formed and characterized by several techniques including DFT and timedependent DFT methods. The calculations agree well with the experimental results and allow the authors to understand the stability of different complexes. Hunstock et al. compared the nonbridged $\left(\mathrm{D}_{3 \mathrm{~h}}\right)$ and doubly bridged $\left(\mathrm{C}_{2 \mathrm{v}}\right)$ structures of trinuclear transition metal carbonyl clusters $\mathrm{M}_{3}(\mathrm{CO})_{12}, \mathrm{M}=\mathrm{Fe}$, $\mathrm{Ru}$ and Os, calculated by using several methods. ${ }^{18}$ They found that DFT was capable to reproduce the energetic preference for the cluster structures with nonbridged carbonyl in osmium and ruthenium clusters. Lokbani-Azzouz et al. performed DFT calculations with LDA and BP functionals on several mixed transition metal-main group metal carbonyl clusters $\mathrm{M}_{4} \mathrm{E}_{2}(\mathrm{CO})_{12}$, $\mathrm{M}=\mathrm{Fe}$, $\mathrm{Ru}$ and $\mathrm{Os}$, and $\mathrm{E}=\mathrm{Bi}, \mathrm{As}, \mathrm{P}, \mathrm{N}, \mathrm{CH}$ and $\mathrm{SiH}$, which exhibit an octahedral core. ${ }^{19}$ Two skeletal structures of $\mathrm{M}_{4}$ in a square or butterfly form are possible. The LDA predicted the correct skeletal topologies of $\mathrm{M}_{4}$ as a square for ruthenium clusters but the carbonyl ligands arrangement is not well predicted. This is acceptable since it is known that a transition from terminal to bridging position required a small amount of energy. ${ }^{1}$ Two skeletal structures of osmium clusters are predicted to be close in energy at the LDA level. This suggests that the energy difference between both skeletal isomers decrease when $\mathrm{M}$ becomes heavier.

Being guided by the success of DFT in structural and spectroscopic prediction in the literature, we performed Density Functional Theory (DFT) calculations to predict the most probable structure of $\left[\mathrm{Os}_{3}(\mathrm{CO})_{11} \mathrm{P}(\mathrm{OMe})_{3}\left(\mathrm{Ru}\left(\eta^{5}-\mathrm{C}_{5} \mathrm{H}_{5}\right)\right)_{2}\right]$ and its spectroscopic information. This method was also applied to $\left[\mathrm{HOs}_{3}\right.$ $\left.(\mathrm{CO})_{11} \mathrm{P}(\mathrm{OMe})_{3} \mathrm{Ru}_{2}\left(\eta^{5}-\mathrm{C}_{5} \mathrm{H}_{5}\right)\left(\mathrm{C}_{5} \mathrm{H}_{4}\right)\right]$ as a validity test. The calculation were verified with all available experimental data.

\section{Methods}

The synthesis and spectroscopic analysis of $\left[\mathrm{Os}_{3}(\mathrm{CO})_{11}\right.$ $\left.\mathrm{P}(\mathrm{OMe})_{3}\left(\mathrm{Ru}\left(\eta^{5}-\mathrm{C}_{5} \mathrm{H}_{5}\right)\right)_{2}\right]$ and $\left[\mathrm{HOs}_{3}(\mathrm{CO})_{11} \mathrm{P}(\mathrm{OMe})_{3} \mathrm{Ru}_{2}\left(\left(\eta^{5}-\right.\right.\right.$ $\left.\mathrm{C}_{5} \mathrm{H}_{5}\right)\left(\mathrm{C}_{5} \mathrm{H}_{4}\right)$ ] have been reported previously as has the structure of the latter cluster. ${ }^{8}$

The Density Functional Theory method (DFT) was used to predict the most probable structural isomer of $\left[\mathrm{Os}_{3}(\mathrm{CO})_{11} \mathrm{P}\right.$ $\left.(\mathrm{OMe})_{3}\left(\mathrm{Ru}\left(\eta^{5}-\mathrm{C}_{5} \mathrm{H}_{5}\right)\right)_{2}\right]$ which is the precursor to $\left[\mathrm{HOs}_{3}(\mathrm{CO})_{11}\right.$ $\mathrm{P}(\mathrm{OMe})_{3} \mathrm{Ru}_{2}\left(\left(\eta^{5}-\mathrm{C}_{5} \mathrm{H}_{5}\right)\left(\mathrm{C}_{5} \mathrm{H}_{4}\right)\right]$. The Local Density Approximation (LDA) and the Perdew-Wang 91 (PW91) exchangecorrelation functionals were employed in combination with the relativistic Stuttgart-Dresden effective core potential (SDD) basis set. The charge density fitting method was used to reduce the computational time. Initially the performance of the chosen methods was verified by comparing the calculated $\left[\mathrm{HOs}_{3}(\mathrm{CO})_{11}\right.$ $\mathrm{P}(\mathrm{OMe})_{3} \mathrm{Ru}_{2}\left(\left(\eta^{5}-\mathrm{C}_{5} \mathrm{H}_{5}\right)\left(\mathrm{C}_{5} \mathrm{H}_{4}\right)\right]$ geometry with the available data from single crystal $\mathrm{X}$-ray diffraction experiment. ${ }^{8}$

Due to a large number of possible isomers of $\left[\mathrm{Os}_{3}(\mathrm{CO})_{11}\right.$ $\left.\mathrm{P}(\mathrm{OMe})_{3}\left(\mathrm{Ru}\left(\eta^{5}-\mathrm{C}_{5} \mathrm{H}_{5}\right)\right)_{2}\right]$, the constrained search for the most probable structural isomer was carried out in two steps as following:

I) Initially, the $\mathrm{P}(\mathrm{OMe})_{3}$ ligand was initially replaced by a
CO ligand. The geometries of six possible arrangements of an edge-bridging tetrahedron of $\left[\mathrm{Os}_{3}(\mathrm{CO})_{12}\left(\mathrm{Ru}\left(\eta^{5}-\right.\right.\right.$ $\left.\left.\mathrm{C}_{5} \mathrm{H}_{5}\right)\right)_{2}$ ] as suggested in Figure 1 were optimized. The lowest energy isomer was selected.

II) A terminal $\mathrm{CO}$ ligand in the lowest energy isomer from previous step was replaced by the $\mathrm{P}(\mathrm{OMe})_{3}$ ligand, hence yielding $\left[\mathrm{Os}_{3}(\mathrm{CO})_{11} \mathrm{P}(\mathrm{OMe})_{3}\left(\mathrm{Ru}\left(\eta^{5}-\mathrm{C}_{5} \mathrm{H}_{5}\right)\right)_{2}\right]$. The steric consideration of the $\mathrm{P}(\mathrm{OMe})_{3}$ ligand was taken into account during this step. The geometry optimization was performed on all generated structures. The most probable isomer is the lowest energy structure.

For all considered structures, the harmonic vibrational frequency was calculated to identify that the isomers are located at the minima on the potential energy surface. The NMR calculations was performed on the most stable isomer by using the IGLO-II basis set which is developed for the ESR and NMR calculations. ${ }^{20}$ The calculated ${ }^{1} \mathrm{H}$ and ${ }^{13} \mathrm{C}$ chemical shielding from tetramethylsilane, TMS, were chosen as a standard reference for ${ }^{1} \mathrm{H}$ and ${ }^{13} \mathrm{C}$ chemical shift whereas the ${ }^{31} \mathrm{P}$ chemical shielding from ${ }^{31} \mathrm{P}(\mathrm{OMe})_{3}$ was chosen as a standard reference for ${ }^{31} \mathrm{P}$ chemical shift.

The activation and reaction energy of the intramolecular hydrogen transfer process were then estimated. The transition state structure connecting the $\left[\mathrm{Os}_{3}(\mathrm{CO})_{11} \mathrm{P}(\mathrm{OMe})_{3}\left(\mathrm{Ru}\left(\eta^{5}-\mathrm{C}_{5} \mathrm{H}_{5}\right)\right)_{2}\right]$ and $\left[\mathrm{HOs}_{3}(\mathrm{CO})_{11} \mathrm{P}(\mathrm{OMe})_{3} \mathrm{Ru}_{2}\left(\left(\eta^{5}-\mathrm{C}_{5} \mathrm{H}_{5}\right)\left(\mathrm{C}_{5} \mathrm{H}_{4}\right)\right]\right.$ was located by the Synchronous Transit-Guided Quasi-Newton (STQN) method developed by Schlegel. ${ }^{21,22}$

All calculations were performed by using the GAUSSIAN 03 package. ${ }^{23}$ The Avogadro software was used to render molecular structures. $^{24}$

\section{Results and Discussion}

Tables 1 and 2 reported some selected bond lengths and bond angles of $\left[\mathrm{HO}_{3}(\mathrm{CO})_{11} \mathrm{P}(\mathrm{OMe})_{3} \mathrm{Ru}_{2}\left(\left(\eta^{5}-\mathrm{C}_{5} \mathrm{H}_{5}\right)\left(\mathrm{C}_{5} \mathrm{H}_{4}\right)\right]\right.$ with the available data from single crystal $\mathrm{X}$-ray diffraction experiment (see Figure 2 for numbering scheme). ${ }^{8}$ This complex has a special bonding arising from the carbon atom in $\mathrm{C}_{5} \mathrm{H}_{4}$ ring that has hydrogen transferred. This carbon atom acts as a bridging

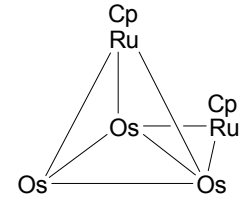

(a)

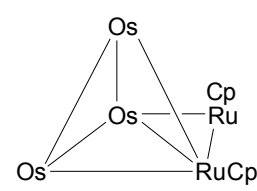

(d)

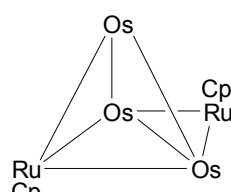

(b)

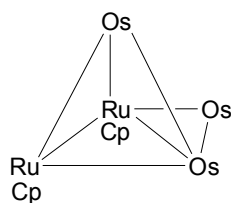

(e)

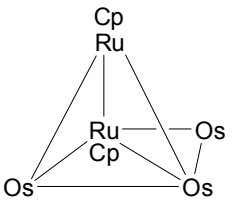

(c)

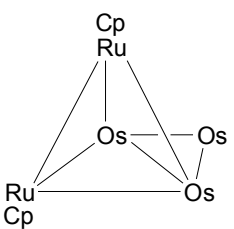

(f)
Figure 1. Six possible arrangements of ruthenium-cyclopentadienyl and osmium carbonyl fragments on edge-bridging tetrahedral geometry of $\mathrm{Os}_{3}(\mathrm{CO})_{11} \mathrm{P}(\mathrm{OMe})_{3}\left(\mathrm{Ru}\left(\eta^{5}-\mathrm{C}_{5} \mathrm{H}_{5}\right)\right)_{2}$. The carbonyl and phosphite ligands were omitted for clarity; their positions were a subject of this study. 
Table 1. Selected calculated bond lengths of $\mathrm{HO}_{3}(\mathrm{CO})_{11} \mathrm{P}(\mathrm{OMe})_{3}$ $\mathrm{Ru}_{2}\left(\eta^{5}-\mathrm{C}_{5} \mathrm{H}_{5}\right)\left(\mathrm{C}_{5} \mathrm{H}_{4}\right)$ molecule compared to the data from single crystal X-ray experiment. The SDD basis set was used in calculations. The root-mean-square error (RMSE) was evaluated using the experimental value as the reference. See Figure 2 for the numbering scheme.

\begin{tabular}{cccc}
\hline Bond length $(\AA)$ & PW91 & LDA & Expt. \\
\hline Os(1)-Os(2) & 3.039 & 2.960 & 2.955 \\
Os(1)-Os(3) & 2.842 & 2.813 & 2.748 \\
Os(2)-Os(3) & 2.885 & 2.806 & 2.791 \\
Os(1)-Ru(4) & 2.790 & 2.737 & 2.877 \\
Os(2)-Ru(4) & 2.928 & 2.789 & 2.927 \\
Os(3)-Ru(4) & 2.772 & 2.737 & 2.893 \\
Os(2)-Ru(5) & 2.844 & 2.802 & 2.817 \\
Os(2)-C(5') & 2.446 & 2.571 & 2.432 \\
$\operatorname{Ru}(5)-\mathrm{C}(5))$ & 2.104 & 2.037 & 2.116 \\
Os(2)-C(52) & 2.080 & 2.053 & 2.052 \\
$\operatorname{Ru}(5)-\mathrm{C}(52)$ & 2.035 & 2.001 & 2.030 \\
Os(1)-H $\mathrm{H}_{\text {transfer }}$ & 1.850 & 1.827 & n.a. \\
Os(2)-H $\mathrm{H}_{\text {transfer }}$ & 1.830 & 1.841 & n.a. \\
RMSE & 0.067 & 0.092 & \\
\hline
\end{tabular}

Table 2. Selected calculated bond angles of $\mathrm{HOs}_{3}(\mathrm{CO})_{11} \mathrm{P}(\mathrm{OMe})_{3} \mathrm{Ru}_{2}$ $\left(\eta^{5}-\mathrm{C}_{5} \mathrm{H}_{5}\right)\left(\mathrm{C}_{5} \mathrm{H}_{4}\right)$ molecule compared to the data from single crystal $\mathrm{X}$-ray experiment. The SDD basis set was used in calculations. The root-mean-square error (RMSE) was evaluated using the experimental value as the reference. See Figure 2 for the numbering scheme.

\begin{tabular}{crrr}
\hline Bond angle $\left({ }^{\circ}\right)$ & PW91 & LDA & Expt. \\
\hline $\mathrm{C}\left(1^{\prime}\right)-\mathrm{C}\left(2^{\prime}\right)-\mathrm{Ru}(4)$ & 72.77 & 69.08 & 71.90 \\
$\mathrm{C}\left(1^{\prime}\right)-\mathrm{C}\left(5^{\prime}\right)-\mathrm{Ru}(4)$ & 68.10 & 66.31 & 69.40 \\
$\mathrm{C}\left(2^{\prime}\right)-\mathrm{C}\left(1^{\prime}\right)-\mathrm{Ru}(4)$ & 70.71 & 72.53 & 70.60 \\
$\mathrm{C}\left(2^{\prime}\right)-\mathrm{C}\left(3^{\prime}\right)-\mathrm{Ru}(4)$ & 70.60 & 70.21 & 71.00 \\
$\mathrm{C}\left(3^{\prime}\right)-\mathrm{C}\left(2^{\prime}\right)-\mathrm{Ru}(4)$ & 72.26 & 72.53 & 72.10 \\
$\mathrm{C}\left(3^{\prime}\right)-\mathrm{C}\left(4^{\prime}\right)-\mathrm{Ru}(4)$ & 71.10 & 71.29 & 72.10 \\
$\mathrm{C}\left(4^{\prime}\right)-\mathrm{C}\left(3^{\prime}\right)-\mathrm{Ru}(4)$ & 72.75 & 71.47 & 71.80 \\
$\mathrm{C}\left(4^{\prime}\right)-\mathrm{C}\left(5^{\prime}\right)-\mathrm{Ru}(4)$ & 68.69 & 69.45 & 68.50 \\
$\mathrm{C}\left(5^{\prime}\right)-\mathrm{C}\left(1^{\prime}\right)-\mathrm{Ru}(4)$ & 75.32 & 75.66 & 74.50 \\
$\mathrm{C}\left(5^{\prime}\right)-\mathrm{C}\left(4^{\prime}\right)-\mathrm{Ru}(4)$ & 74.65 & 72.94 & 73.90 \\
$\mathrm{O}(21)-\mathrm{C}(21)-\mathrm{Os}(2)$ & 179.41 & 179.05 & 179.00 \\
$\mathrm{O}(22)-\mathrm{C}(22)-\mathrm{Os}(2)$ & 172.44 & 172.22 & 172.10 \\
$\mathrm{O}(51)-\mathrm{C}(51)-\mathrm{Ru}(5)$ & 176.10 & 178.50 & 176.40 \\
$\mathrm{O}(52)-\mathrm{C}(52)-\mathrm{Os}(2)$ & 137.78 & 138.68 & 137.00 \\
$\mathrm{O}(52)-\mathrm{C}(52)-\mathrm{Ru}(5)$ & 134.73 & 133.71 & 135.70 \\
Os(1)-H $\mathrm{H}_{\text {transfer- }} \mathrm{Os}(2)$ & 111.3 & 107.6 & n.a. \\
RMSE & 0.72 & 1.57 & \\
\hline
\end{tabular}

Table 3. The energy of six isomers (a)-(f) of $\mathrm{Os}_{3}(\mathrm{CO})_{12}\left(\mathrm{Ru}\left(\eta^{5}-\mathrm{C}_{5} \mathrm{H}_{5}\right)\right)_{2}$ relative to that of the lowest energy isomer (a)

\begin{tabular}{ccc}
\hline $\mathrm{Os}_{3}(\mathrm{CO})_{12}\left(\mathrm{Ru}\left(\eta^{5}-\mathrm{C}_{5} \mathrm{H}_{5}\right)\right)_{2}$ & \multicolumn{2}{c}{ Relative energy $(\mathrm{kcal} / \mathrm{mol})$} \\
\cline { 2 - 3 } isomers & PW91 & LDA \\
\hline (a) & 0.00 & 0.00 \\
$(\mathbf{b})$ & 17.81 & 17.30 \\
$($ c) & 29.01 & 26.44 \\
$($ d) & 25.21 & 26.81 \\
$($ e) & 28.80 & 27.70 \\
(f) & 9.32 & 8.91 \\
\hline
\end{tabular}

(a)

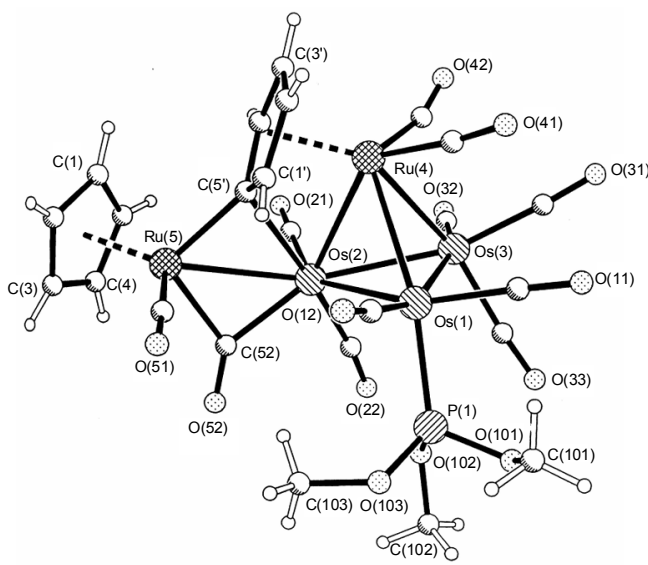

(b)

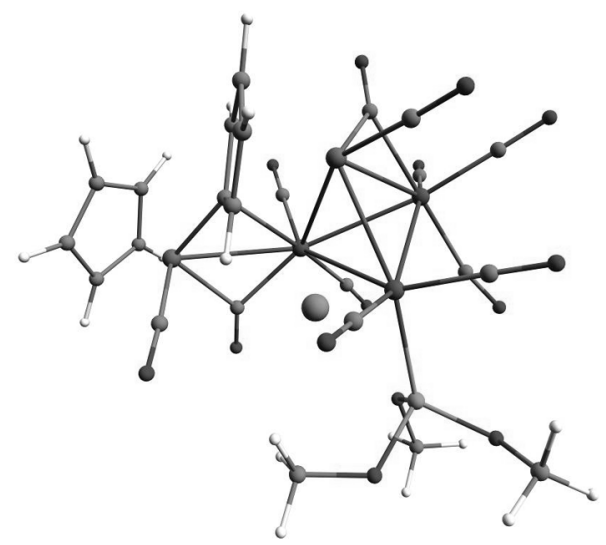

Figure 2. The structure of $\mathrm{HOs}_{3}(\mathrm{CO})_{11} \mathrm{P}(\mathrm{OMe})_{3} \mathrm{Ru}_{2}\left(\eta^{5}-\mathrm{C}_{5} \mathrm{H}_{5}\right)\left(\mathrm{C}_{5} \mathrm{H}_{4}\right)$ from (a) X-ray and (b) PW91/SDD calculation with the numbering as used in Tables 1 and 2 . The transferred hydrogen is highlighted.

ligand donating its electron to $\mathrm{Ru}(5)$ and $\mathrm{Os}(2)$ atoms. The optimized geometries from both functionals are in very good agreement with the experiment. The PW91/SDD performs slightly better than the LDA/SDD as a result of the generalized gradient approximation. As it is well known that X-ray diffraction experiment can not detect the hydrogen position, the calculation shows clear advantage in locating the transferred hydrogen in the complex. It situates in a bridging position between Os(1) and Os(2) atom with almost equal distances around $1.8 \AA$.

Six possible arrangements of $\left[\mathrm{Os}_{3}(\mathrm{CO})_{12}\left(\mathrm{Ru}\left(\eta^{5}-\mathrm{C}_{5} \mathrm{H}_{5}\right)\right)_{2}\right]$ as suggested in Figure 1 were optimized. Figure 3 displayed the PW91/SDD optimized structures of all isomers. The isomer (a) with one $\mathrm{Ru}\left(\eta^{5}-\mathrm{C}_{5} \mathrm{H}_{5}\right)$ fragment at the edge-bridging position is the lowest energy isomer. Table 3 reports the energy of $\left[\mathrm{Os}_{3}(\mathrm{CO})_{12}\left(\mathrm{Ru}\left(\eta^{5}-\mathrm{C}_{5} \mathrm{H}_{5}\right)\right)_{2}\right]$ isomers relative to that of isomer (a). The greater energy of other isomers rules out the possibility of co-existence with the lowest-energy isomer. The metal arrangement of isomer (a) will be used in step II of constrained search. Both LDA and PW91 functionals yield the isomeric energy in the same order. The structure of isomers (c), (d) and (e) are less favorable due to the steric clash between the cyclopentadienyl rings on adjacent ruthenium atoms. The metal-metal bond distances of isomer $(\mathbf{a})$ of $\left[\mathrm{Os}_{3}(\mathrm{CO})_{12}\left(\mathrm{Ru}\left(\eta^{5}-\mathrm{C}_{5} \mathrm{H}_{5}\right)\right)_{2}\right]$ range from $2.751 \AA(\mathrm{Os}(1)-\mathrm{Os}(2))$ to $2.934 \AA(\mathrm{Os}(2)-\mathrm{Os}(3))$ at the PW91/SDD level and from $2.690 \AA(\mathrm{Os}(1)-\mathrm{Os}(2))$ to $2.861 \AA$ 
(a)

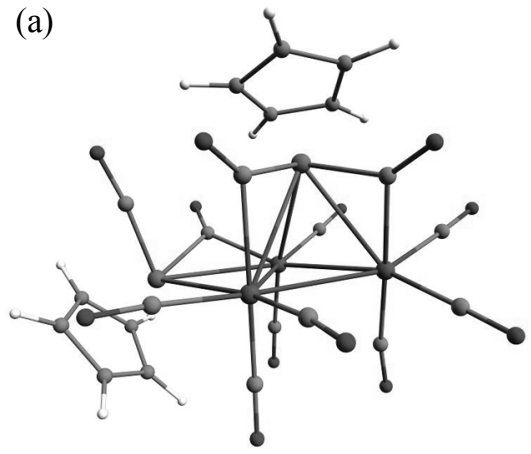

(d)

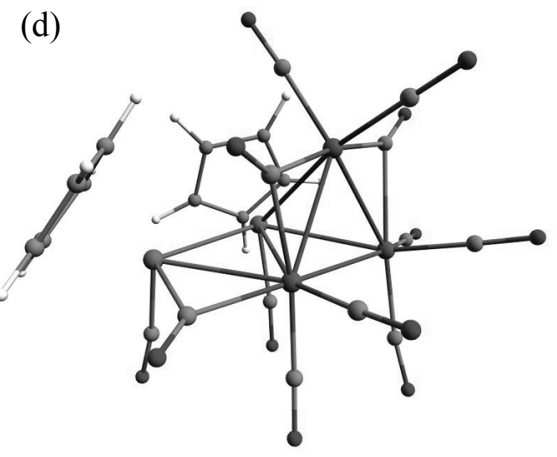

(b)
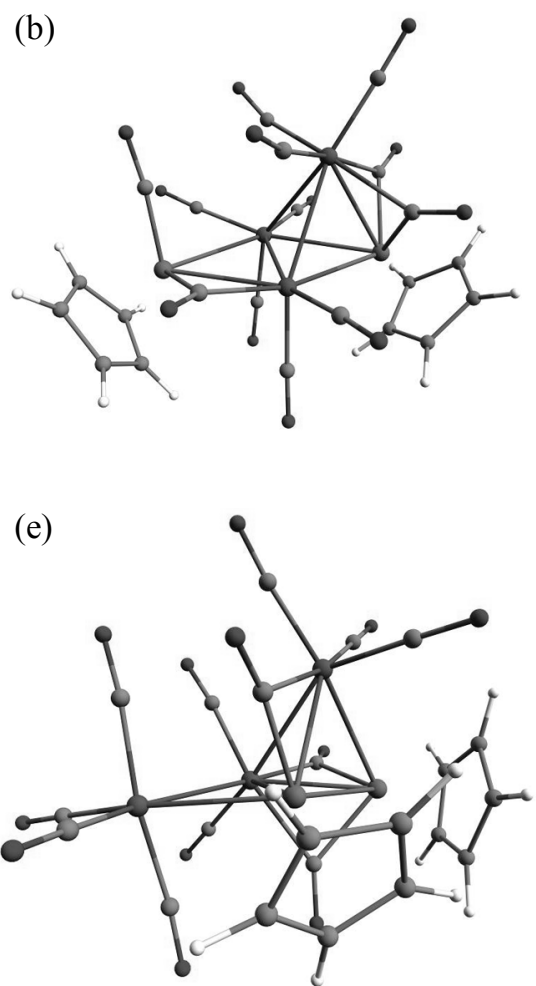

(c)

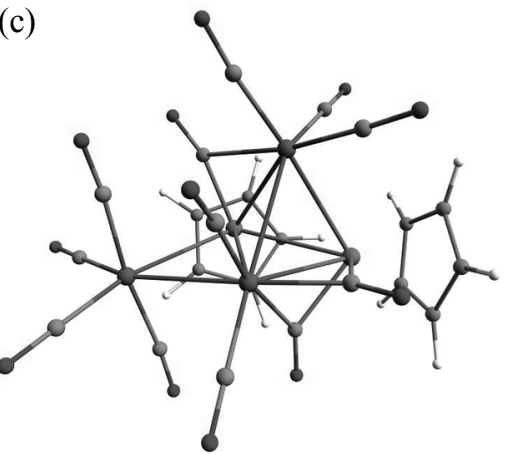

(f)
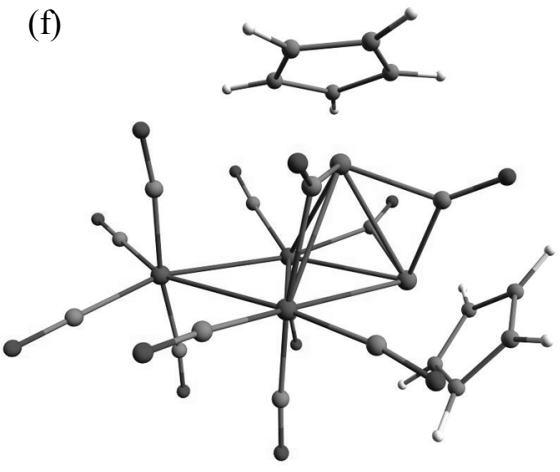

Figure 3. The PW91/SDD optimized geometries of six possible isomers (a)-(f) of $\mathrm{Os}_{3}(\mathrm{CO})_{12}\left(\mathrm{Ru}\left(\eta^{5}-\mathrm{C}_{5} \mathrm{H}_{5}\right)\right)_{2}$.

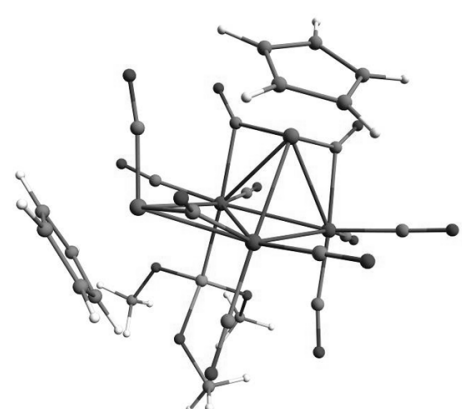

(a1)

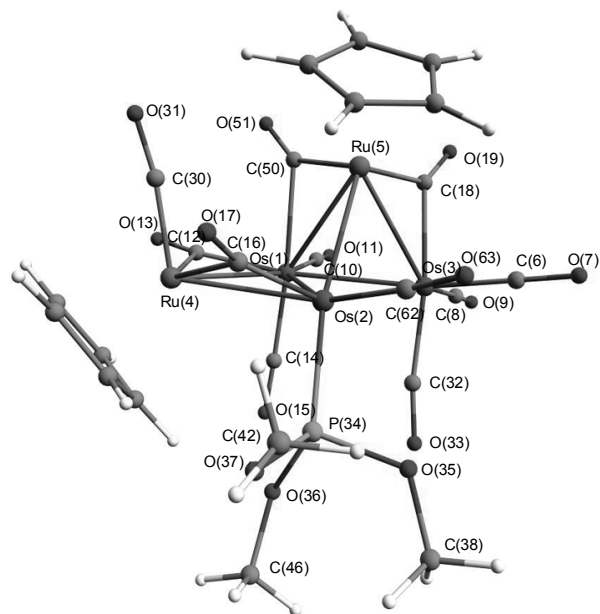

(a2)

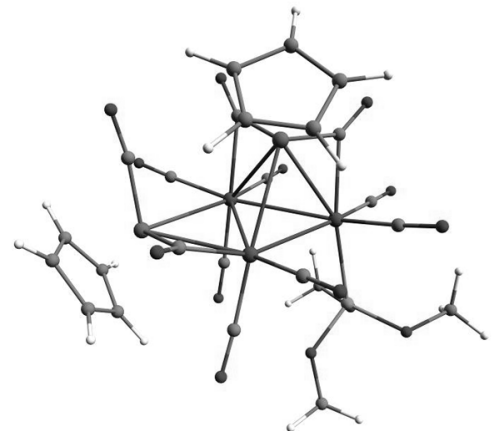

(a3)

Figure 4. The PW91/SDD optimized geometries of three possible isomers (a1)-(a3) of $\mathrm{Os}_{3}(\mathrm{CO})_{11} \mathrm{P}(\mathrm{OMe})_{3}\left(\mathrm{Ru}\left(\eta^{5}-\mathrm{C}_{5} \mathrm{H}_{5}\right)\right)_{2}$. The numbering as used in Tables 5 and 6 is shown in the isomer (a2).

(Os(2)-Os(3)) at the LDA/SDD level. These distances are comparable to those found in other simple polynuclear osmiumruthenium carbonyl clusters. ${ }^{25}$ The PW91/SDD predicts bond lengths slightly greater than those from LDA/SDD method but both calculations yield reasonable bond lengths.

Taking isomer (a) as starting point for step II of constrained search, a carbonyl ligand was replaced by a bulky phosphite, $\mathrm{P}(\mathrm{OMe})_{3}$, ligand taking the steric effect into account. From the $107^{\circ}$ cone angle of the phosphite ligand ${ }^{9}$ and the study of similar $\mathrm{Os}_{5}(\mathrm{CO})_{\mathrm{n}}\left(\mathrm{PMe}_{3}\right)$ compounds by Wang et al., ${ }^{26}$ the ligand replacement was limited to the three possible axial positions.
Figure 4 shows the optimized geometries of three isomers identified as (a1)-(a3).

Both the PW91/SDD and LDA/SDD methods indicated that the isomer $(\mathbf{a} 2)$ is the most probable geometry of $\left[\mathrm{Os}_{3}(\mathrm{CO})_{11}\right.$ $\left.\mathrm{P}(\mathrm{OMe})_{3}\left(\mathrm{Ru}\left(\eta^{5}-\mathrm{C}_{5} \mathrm{H}_{5}\right)\right)_{2}\right]$. Table 4 reports the energy of the three proposed isomers of $\left[\mathrm{Os}_{3}(\mathrm{CO})_{11} \mathrm{P}(\mathrm{OMe})_{3}\left(\mathrm{Ru}\left(\eta^{5}-\mathrm{C}_{5} \mathrm{H}_{5}\right)\right)_{2}\right]$ relative to that of isomer (a2). The energetic difference among these three isomers due to the relocation of phosphite ligand is much less than the energetic difference among six possible transitionmetal arrangements in step I of constrained search. Hence we believe that a constrained search is justified. 
Table 4. The energy of three isomers $(\mathbf{a 1})-(\mathbf{a} 3)$ of $_{3}(\mathrm{CO})_{11} \mathrm{P}(\mathrm{OMe})_{3}$ $\left(\mathrm{Ru}\left(\eta^{5}-\mathrm{C}_{5} \mathrm{H}_{5}\right)\right)_{2}$ relative to that of the lowest energy isomer (a2)

\begin{tabular}{ccc}
\hline $\mathrm{Os}_{3}(\mathrm{CO})_{11} \mathrm{P}(\mathrm{OMe})_{3}\left(\mathrm{Ru}\left(\eta^{5}-\mathrm{C}_{5} \mathrm{H}_{5}\right)\right)_{2}$ & \multicolumn{2}{c}{ Relative energy $(\mathrm{kcal} / \mathrm{mol})$} \\
\cline { 2 - 3 } & PW91 & LDA \\
\hline$(\mathbf{a} 1)$ & 1.87 & 1.03 \\
$(\mathbf{a} 2)$ & 0.00 & 0.00 \\
$(\mathbf{a})$ & 5.36 & 1.32 \\
\hline
\end{tabular}

Table 5. The selected bond lengths of isomer (a2) of $\mathrm{Os}_{3}(\mathrm{CO})_{11}$ $\mathrm{P}(\mathrm{OMe})_{3}\left(\mathrm{Ru}\left(\eta^{5}-\mathrm{C}_{5} \mathrm{H}_{5}\right)\right)_{2}$. See Figure 4 for the numbering scheme.

\begin{tabular}{ccc}
\hline \multirow{2}{*}{$\mathrm{Os}_{3}(\mathrm{CO})_{11} \mathrm{P}(\mathrm{OMe})_{3}\left(\mathrm{Ru}\left(\eta^{5}-\mathrm{C}_{5} \mathrm{H}_{5}\right)\right)_{2}$} & \multicolumn{2}{c}{ Bond length $(\AA)$} \\
\cline { 2 - 3 } $\mathrm{Os}(1)-\mathrm{Os}(2)$ & 2.723 & 2.747 \\
$\mathrm{Os}(1)-\mathrm{Os}(3)$ & 2.810 & 2.706 \\
$\mathrm{Os}(2)-\mathrm{Os}(3)$ & 2.915 & 2.897 \\
$\mathrm{Os}(1)-\mathrm{Ru}(4)$ & 2.872 & 2.753 \\
$\mathrm{Os}(1)-\mathrm{Ru}(5)$ & 2.835 & 2.815 \\
$\mathrm{Os}(2)-\mathrm{Ru}(4)$ & 2.903 & 2.812 \\
$\mathrm{Os}(2)-\mathrm{Ru}(5)$ & 2.845 & 2.802 \\
$\mathrm{Os}(3)-\mathrm{Ru}(5)$ & 2.779 & 2.665 \\
$\mathrm{Os}(1)-\mathrm{C}(12)$ & 1.987 & 2.058 \\
$\mathrm{Ru}(4)-\mathrm{C}(12)$ & 2.167 & 2.000 \\
$\mathrm{Os}(2)-\mathrm{C}(18)$ & 2.200 & 2.162 \\
$\mathrm{Ru}(5)-\mathrm{C}(18)$ & 1.961 & 1.938 \\
$\mathrm{Os}(3)-\mathrm{C}(20)$ & 2.215 & 2.141 \\
$\mathrm{Ru}(5)-\mathrm{C}(20)$ & 1.962 & 1.964 \\
$\mathrm{Ru}(4)-\mathrm{C}(38)$ & 2.274 & 2.227 \\
$\mathrm{Ru}(5)-\mathrm{C}(26)$ & 2.292 & 2.230 \\
$\mathrm{Os}(2)-\mathrm{P}(46)$ & 2.367 & 2.316 \\
& &
\end{tabular}

Table 6. The selected bond angles of isomer $(\mathbf{a} 2)$ of $\mathrm{Os}_{3}(\mathrm{CO})_{11} \mathrm{P}(\mathrm{OMe})_{3}$ $\left(\mathrm{Ru}\left(\eta^{5}-\mathrm{C}_{5} \mathrm{H}_{5}\right)\right)_{2}$. See Figure 4 for the numbering scheme.

\begin{tabular}{crr}
\hline & \multicolumn{2}{c}{ Bond angle $\left(^{\circ}\right)$} \\
\cline { 2 - 3 } $\mathrm{Os}_{3}(\mathrm{CO})_{11} \mathrm{P}(\mathrm{OMe})_{3}\left(\mathrm{Ru}\left(\eta^{5}-\mathrm{C}_{5} \mathrm{H}_{5}\right)\right)_{2}$ & $\mathrm{PW} 91$ & \multicolumn{1}{c}{$\mathrm{LDA}$} \\
\hline $\mathrm{Os}(1)-\mathrm{Ru}(4)-\mathrm{Os}(2)$ & 56.27 & 59.14 \\
$\mathrm{Os}(1)-\mathrm{C}(10)-\mathrm{O}(11)$ & 177.76 & 176.06 \\
$\mathrm{Os}(1)-\mathrm{C}(12)-\mathrm{O}(13)$ & 145.99 & 139.03 \\
$\mathrm{Os}(1)-\mathrm{C}(14)-\mathrm{O}(15)$ & 176.20 & 176.10 \\
$\mathrm{Os}(2)-\mathrm{C}(16)-\mathrm{O}(17)$ & 155.91 & 173.78 \\
$\mathrm{Os}(2)-\mathrm{C}(62)-\mathrm{O}(63)$ & 176.40 & 174.45 \\
$\mathrm{Os}(1)-\mathrm{Os}(2)-\mathrm{P}(46)$ & 94.91 & 89.19 \\
$\mathrm{Os}(3)-\mathrm{C}(6)-\mathrm{O}(7)$ & 177.59 & 177.60 \\
$\mathrm{Os}(3)-\mathrm{C}(8)-\mathrm{O}(9)$ & 177.79 & 176.93 \\
$\mathrm{Os}(3)-\mathrm{C}(44)-\mathrm{O}(45)$ & 168.72 & 153.45 \\
$\operatorname{Ru}(4)-\mathrm{C}(42)-\mathrm{O}(43)$ & 171.08 & 170.83 \\
$\mathrm{Ru}(5)-\mathrm{C}(18)-\mathrm{O}(19)$ & 141.17 & 140.85 \\
$\mathrm{Ru}(5)-\mathrm{C}(20)-\mathrm{O}(21)$ & 141.70 & 140.53 \\
$\mathrm{Os}(1)-\mathrm{Ru}(4)-\mathrm{C}(38)$ & 135.48 & 140.74 \\
$\mathrm{Ru}(4)-\mathrm{C}(38)-\mathrm{C}(36)$ & 70.38 & 69.95 \\
$\mathrm{Os}(2)-\mathrm{Ru}(5)-\mathrm{C}(26)$ & 138.27 & 137.52 \\
$\mathrm{Ru}(5)-\mathrm{C}(26)-\mathrm{C}(28)$ & 72.14 & 71.47 \\
\hline
\end{tabular}

Table 7. The CO stretching frequencies of $\mathrm{Os}_{3}(\mathrm{CO})_{11} \mathrm{P}(\mathrm{OMe})_{3}\left(\mathrm{Ru}\left(\eta^{5}-\right.\right.$ $\left.\left.\mathrm{C}_{5} \mathrm{H}_{5}\right)\right)_{2}$

$$
v(\mathrm{CO})\left(\mathrm{cm}^{-1}\right)
$$

\begin{tabular}{cl}
\hline PW91 & $1724,1749,1859,1863,1878,1899,1941$ \\
LDA & $1738,1785,1925,1935,1956,1966,1989$ \\
Expt. & $1716,1772,1933,1976,1991,2000,2039$ \\
\hline
\end{tabular}

The edge-bridging tetrahedral structure of $\left[\mathrm{Os}_{3}(\mathrm{CO})_{11} \mathrm{P}(\mathrm{OMe})_{3}\right.$ $\left.\left(\mathrm{Ru}\left(\eta^{5}-\mathrm{C}_{5} \mathrm{H}_{5}\right)\right)_{2}\right]$ has the phosphite ligand attached to the $\mathrm{Os}(2)$ atom (see Figure 4 ). The next most likely phosphite position is at Os(1) atom. By simple consideration, the (a1) and (a2) should be equivalent by symmetry but the calculation however indicated a slight energy difference. This might be due to a small distortion in the optimized geometry. The (a) $\mathbf{a})$ isomer is the least probable (highest energy) among the three isomers. Although the PW91/SDD and LDA/SDD results provide a similar qualitative trend, the preferential position of phosphite ligand can be observed clearly in the PW91/SDD level which is a better approximation than the LDA/SDD level.

Tables 5 and 6 reported selected bond lengths and bond angles of the isomer (a2) respectively (see Figure 4 for numbering scheme). The Os(2)-P(46) bond length is $2.367 \AA$ for the PW91/ SDD level and $2.316 \AA$ for the LDA/SDD level, respectively. There are seven terminal carbonyl ligands and four bridging carbonyl ligands spanning the Os(1)-Ru(4), Os(2)-Ru(4), Os(2)$\mathrm{Ru}(5)$, and $\mathrm{Os}(3)-\mathrm{Ru}(5)$ edges. Overall, as expected, the metalcarbon bonds connecting bridging carbonyl ligands are longer than those connecting terminal carbonyl ligands. The metalmetal bond distances are in the range of $2.723 \AA(\mathrm{Os}(1)-\mathrm{Os}(2))$ to $2.915 \AA(\mathrm{Os}(2)-\mathrm{Os}(3))$ at PW91/SDD level and of $2.665 \AA$ $(\mathrm{Os}(3)-\mathrm{Ru}(5))$ to $2.897 \AA(\mathrm{Os}(2)-\mathrm{Os}(3))$ at LDA/SDD level. Upon replacing one $\mathrm{CO}$ by $\mathrm{P}(\mathrm{OMe})_{3}$, the $\mathrm{Os}(1)-\mathrm{Ru}(4)-\mathrm{Os}(2)$ bond angles change slightly and the $\mathrm{Os}(2)-\mathrm{Ru}(4)$ bond distances change only marginally ( $0.001 \AA$ at PW91/SDD level and $0.004 \AA$ at LDA/SDD level). The metal-metal bond lengths from both levels exhibit the same trend and lie in the expected range when compared to the experimental data of the other simple polynuclear osmium-ruthenium carbonyl clusters. ${ }^{25}$

To verify our predicted geometry, the vibrational spectra and the NMR chemical shift were calculated and verified against available experimental data. The vibrational frequencies of $\left[\mathrm{Os}_{3}(\mathrm{CO})_{11} \mathrm{P}(\mathrm{OMe})_{3}\left(\mathrm{Ru}\left(\eta^{5}-\mathrm{C}_{5} \mathrm{H}_{5}\right)\right)_{2}\right]$ were calculated at both PW91/SDD and LDA/SDD levels. The calculated carbonyl stretching vibrational frequencies are summarized in Table 7. Both functionals yield the frequencies in the same range as the experimental values although they are not in a perfect quantitative agreement. It seems that LDA/SDD method is more appropriate for the IR calculation than the PW91/SDD method. From calculations, the stretching frequencies fall into two groups. The lower stretching frequency modes were identified to be those of bridging carbonyl ligands while the higher frequency modes correspond to those of terminal carbonyl ligands. Both methods reproduce the $\mathrm{CO}$ stretching of bridging carbonyl ligands well while those of terminal ones are underestimated. This might be due to the neglect of solvent effect in our calculation. We expect 
Table 8. The predicted NMR chemical shift of $\mathrm{Os}_{3}(\mathrm{CO})_{11} \mathrm{P}(\mathrm{OMe})_{3}$ $\left(\mathrm{Ru}\left(\eta^{5}-\mathrm{C}_{5} \mathrm{H}_{5}\right)\right)_{2}$. The IGLO-II basis set was used in all calculations. To compare with the room-temperature experimental data, the calculated results were averaged among all equivalent nuclei.

\begin{tabular}{crrrr}
\hline $\begin{array}{c}\text { Chemical } \\
\text { Shift }(\mathrm{ppm})\end{array}$ & PW91 & LDA & OPBE & Expt. \\
\hline${ }^{1} \mathrm{H}$ & 4.18 & 4.53 & 3.90 & 3.58 \\
${ }^{1} \mathrm{H}$ & 5.36 & 5.47 & 5.08 & 5.39 \\
${ }^{13} \mathrm{C}$ & 102.77 & 105.23 & 93.99 & 88.80 \\
${ }^{13} \mathrm{C}$ & 104.97 & 105.15 & 96.79 & 90.68 \\
${ }^{13} \mathrm{C}$ & 64.9 & 64.16 & 60.74 & 53.65 \\
${ }^{31} \mathrm{P}$ & -16.56 & -41.78 & -39.78 & -36.06 \\
\hline
\end{tabular}

that, upon including solvent effect, the calculated stretching frequency will be red-shifted and match the experimental data better.

Table 8 reports the ${ }^{1} \mathrm{H},{ }^{13} \mathrm{C}$, and ${ }^{31} \mathrm{P}$ NMR chemical shifts of $\left[\mathrm{Os}_{3}(\mathrm{CO})_{11} \mathrm{P}(\mathrm{OMe})_{3}\left(\mathrm{Ru}\left(\eta^{5}-\mathrm{C}_{5} \mathrm{H}_{5}\right)\right)_{2}\right]$ calculated by using the PW91, LDA and OPBE exchange-correlation functionals with the IGLO-II basis set. The PW91 and LDA functionals did not performed well when compared to the experimental chemical shift. The agreement with the experiment improves when the OPBE functional was used. ${ }^{27}$ Given that it is much more difficult to compute the chemical shifts, our agreement from OPBE/ IGLO-II method is acceptable. The calculation can be used to characterize and explain the experimental spectrum. The experimental ${ }^{1} \mathrm{H}$ shifts at 3.58 and $5.39 \mathrm{ppm}$ correspond to the proton from the methyl groups of the phosphite ligand and the cyclopentadiene ring, respectively. The ${ }^{13} \mathrm{C}$ shifts at $88.80 \mathrm{ppm}$ and 90.68 ppm are from two non-identical cyclopentadienyl rings bonded to ruthenium atoms. The ${ }^{13} \mathrm{C}$ shift at $53.65 \mathrm{ppm}$ is from the methyl carbon of the phosphite ligand. The experimental ${ }^{31} \mathrm{P}$ shift at $-36.06 \mathrm{ppm}$ of phosphite ligand was predicted by the OPBE/IGLO-II level to be $-39.78 \mathrm{ppm}$ which is in acceptable agreement.

Furthermore, the isomer (a2) has the structure that correlates best with the available single crystal X-ray structure of $\left[\mathrm{HOs}_{3}\right.$ $\left.(\mathrm{CO})_{11} \mathrm{P}(\mathrm{OMe})_{3} \mathrm{Ru}_{2}\left(\eta^{5}-\mathrm{C}_{5} \mathrm{H}_{5}\right)\left(\mathrm{C}_{5} \mathrm{H}_{4}\right)\right]$ which is the product of thermal intramolecular hydrogen transfer (see Figure 2). This experimental evidence helps justifying the employed DFT method which, in general case, might not be adequate to distinguish between isomers with small energy differences. ${ }^{28,29}$ With all available data, we therefore conclude that the isomer (a2) in which the phosphite, $\mathrm{P}(\mathrm{OMe})_{3}$, occupies an axial position on one of the two osmium atoms that is edge bridged by the $\mathrm{Ru}(\mathrm{CO})_{2}$ $\left(\eta^{5}-\mathrm{C}_{5} \mathrm{H}_{5}\right)$ unit should be the most probable structure of $\left[\mathrm{Os}_{3}\right.$ $\left.(\mathrm{CO})_{11} \mathrm{P}(\mathrm{OMe})_{3}\left(\mathrm{Ru}\left(\eta^{5}-\mathrm{C}_{5} \mathrm{H}_{5}\right)\right)_{2}\right]$.

The intramolecular hydrogen transfer converts $\left[\mathrm{Os}_{3}(\mathrm{CO})_{11}\right.$ $\left.\mathrm{P}(\mathrm{OMe})_{3}\left(\mathrm{Ru}\left(\eta^{5}-\mathrm{C}_{5} \mathrm{H}_{5}\right)\right)_{2}\right]$ to $\left[\mathrm{HOs}_{3}(\mathrm{CO})_{11} \mathrm{P}(\mathrm{OMe})_{3} \mathrm{Ru}_{2}\left(\left(\eta^{5}-\mathrm{C}_{5} \mathrm{H}_{5}\right)\right.\right.$ $\left.\left(\mathrm{C}_{5} \mathrm{H}_{4}\right)\right]$. This involves breaking of the hydrogen-carbon bond from one cyclopentadienyl ring and making the hydrogenosmium bond. This process caused a square-based tetrahedral framework to become a spiked tetrahedral framework by elongating one Os-edge bridged Ru bond. A corresponding transition state structure was located with a large imaginary frequency of $944.81 \mathrm{~cm}^{-1}$ corresponding to the hydrogen transfer motion from cyclopentadienyl ring to the bridging position of Os(1)-

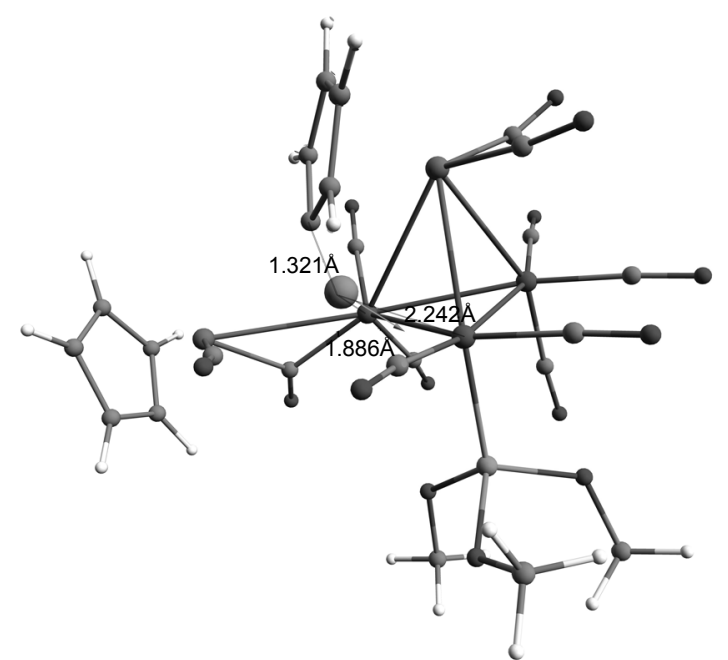

Figure 5. The PW91/SDD optimized transition state structure of intramolecular hydrogen transfer step with the transferred hydrogen being highlighted. The corresponding reaction coordinate is represented by the displacement arrow vectors.

Os(2) bond (see Figure 5). The intrinsic reaction coordinate calculations confirms that this transition state indeed links the correct reactant and product. This transition state structure has a elongated $\mathrm{C}(58)-\mathrm{H}(63)$ bond length of $1.321 \AA$ in comparison to other $\mathrm{C}-\mathrm{H}$ bond lengths. The activation and reaction energy of intramolecular hydrogen transfer are $110.32 \mathrm{kcal} / \mathrm{mol}$ and 110.32 and $-0.14 \mathrm{kcal} / \mathrm{mol}$. They were estimated only at the PW91/SDD method. The LDA/SDD level was not used because the LDA functional was known to overestimate the energy involving in the breaking and forming of the chemical bond. The activation energy of this process is relatively high while the reaction energy change is very small. The almost zero value of reaction energy could possibly imply that reactant and product are stable to the same extent. The reason that both two structures does not immediately convert to each other might be explained from a very high activation energy. This is in agreement with what observed in the experiment that one needs to reflux the reactant at high temperature in order to convert it to become the product. A detailed investigation on the reaction mechanism of this important intramolecular hydrogen transfer will be discussed in separate communication.

\section{Conclusion}

By using a constrained search, the prediction of possible isomeric structure of $\left[\mathrm{Os}_{3}(\mathrm{CO})_{11} \mathrm{P}(\mathrm{OMe})_{3}\left(\mathrm{Ru}\left(\eta^{5}-\mathrm{C}_{5} \mathrm{H}_{5}\right)\right)_{2}\right]$ was carried out in two steps. This reduces the computational cost of exploring many possible isomers. The most possible structure is the isomer (a2) in which $\mathrm{P}(\mathrm{OMe})_{3}$ occupies an axial position on one of the two osmium atoms that is edge bridged by the $\mathrm{Ru}(\mathrm{CO})_{2}\left(\eta^{5}-\mathrm{C}_{5} \mathrm{H}_{5}\right)$ unit. This is verified by calculating the IR and NMR data and comparing them with the available experimental data. The calculated method must be carefully selected for the IR and NMR predictions while the structural prediction is less susceptible to the used method. The isomer (a2) also correlates well with $\left[\mathrm{HOs}_{3}(\mathrm{CO})_{11} \mathrm{P}(\mathrm{OMe})_{3} \mathrm{Ru}_{2}\left(\left(\eta^{5}-\mathrm{C}_{5} \mathrm{H}_{5}\right)\left(\mathrm{C}_{5} \mathrm{H}_{4}\right)\right]\right.$ 
which is the product of intramolecular hydrogen transfer process. The high activation and almost zero reaction energy might explain the observation that two complexes are stable and can convert from one form to another only by reflux in toluene.

Acknowledgments. R. B. thanks University of Cambridge, Cambridge Overseas Trust, Cambridge Thai Foundation, the Institute for the Promotion of Teaching Science and Technology, Silpakorn University for financial supports. Y. T. acknowledges supports from the National Nanotechnology Center (to NANOSIM) and the Thailand Research Fund (RSA5180010). Computational facility from the high-performance computing cluster (HPCC), the National Electronics and Computer Technology Center (NECTEC) is gratefully acknowledged.

\section{References}

1. Mingos, D. M. P.; Wales, D. J. Introduction to Cluster Chemistry; Prentice-Hall: Englewood Cliffs, 1990.

2. Sergeev, G. B. Nanochemistry; Elsevier: Amsterdam, 2006.

3. Mauro, M.; Panigati, M.; Donghi, D.; Mercandelli, P.; Mussini, P.; Sironi, A.; D'Alfonso, G. Inorg. Chem. 2008, 47, 11154.

4. Beltran, L. M. C.; Long, J. R. Acc. Chem. Res. 2005, 38, 325.

5. Edwards, A. J.; Lewis, J.; Li, C.-K.; Morewood, C. A.; Raithby, P. R.; Shields, G. P. Polyhedron 2006, 25, 211.

6. Al-Mandhary, M.; Buntem, R.; Doherty, C.; Edwards, A.; Gallagher, J.; Lewis, J.; Li, C.-K.; Raithby, P.; Ramirez de Arellano, M.; Shields, G. Journal of Cluster Science 16, 127.

7. Buntem, R.; Lewis, J.; Morewood, C. A.; Raithby, P. R.; Ramirez de Arellano, M. C.; Shields, G. P. J. Chem. Soc., Dalton Trans. 1998, 1091.

8. Buntem, R.; Gallagher, J. F.; Lewis, J.; Raithby, P. R.; Rennie, M.-A.; Shields, G. P. J. Chem. Soc., Dalton Trans. 2000, 4297.

9. White, C.; Thomson, J.; Maitlis, P. M. J. Chem. Soc., Dalton Trans. 1977, 1654.

10. Bennett, M. A.; Smith, K. J. Chem. Soc., Dalton Trans. 1974, 233.

11. Lewis, J. Unpublished work.

12. Gill, T. P.; Mann, K. R. Organometallics 1982, 1, 485.

13. Elian, M.; Chen, M. M. L.; Mingos, D. M. P.; Hoffmann, R. Inorg. Chem. 1976, 15, 1148.

14. Buntem, R. Synthetic Studies in Carbonyl Cluster Compounds of
Osmium; University of Cambridge: Cambridge, 1995.

15. Cramer, C. J. Essentials of Computational Chemistry: Theories and Models, 2nd ed.; Wiley: UK, 2003.

16. Neese, F. J. Biol. Inorg. Chem. 2006, 11, 702.

17. Ray, K.; Petrenko, T.; Wieghardt, K.; Neese, F. Dalton Trans. 2007, 1552.

18. Hunstock, E.; Mealli, C.; Calhorda, M. J.; Reinhold, J. Inorg. Chem. 1999, 38, 5053.

19. Lokbani-Azzouz, N. S.; Boucekkine, A.; Halet, J.-F.; Saillard, J.-Y. J. Cluster Sci. 2003, 14, 49.

20. Kutzelnigg, W.; Fleischer, U.; Schindler, M. The IGLO-Method: Ab-initio Calculation and Interpretation of NMR Chemical Shifts and Magnetic Susceptibilities; Springer: Berlin, 1991.

21. Peng, C.; Ayala, P. Y.; Schlegel, H. B.; Frisch, M. J. J. Comp. Chem. 1996, 17, 49 .

22. Peng, C.; Schlegel, H. B. Israel J. of Chem. 1993, 449.

23. Frisch, M. J.; Trucks, G. W.; Schlegel, H. B.; Scuseria, G. E.; Robb, M. A.; Cheeseman, J. R.; Montgomery, J.; Vreven, T.; Kudin, K. N.; Burant, J. C.; Millam, J. M.; Iyengar, S. S.; Tomasi, J.; Barone, V.; Mennucci, B.; Cossi, M.; Scalmani, G.; Rega, N.; Petersson, G. A.; Nakatsuji, H.; Hada, M.; Ehara, M.; Toyota, K.; Fukuda, R.; Hasegawa, J.; Ishida, M.; Nakajima, T.; Honda, Y.; Kitao, O.; Nakai, H.; Klene, M.; Li, X.; Knox, J. E.; Hratchian, H. P.; Cross, J. B.; Bakken, V.; Adamo, C.; Jaramillo, J.; Gomperts, R.; Stratmann, R. E.; Yazyev, O.; Austin, A. J.; Cammi, R.; Pomelli, C.; Ochterski, J. W.; Ayala, P. Y.; Morokuma, K.; Voth, G. A.; Salvador, P.; Dannenberg, J. J.; Zakrzewski, V. G.; Dapprich, S.; Daniels, A. D.; Strain, M. C.; Farkas, O.; Malick, D. K.; Rabuck, A. D.; Raghavachari, K.; Foresman, J. B.; Ortiz, J. V.; Cui, Q.; Baboul, A. G.; Clifford, S.; Cioslowski, J.; Stefanov, B. B.; Liu, G.; Liashenko, A.; Piskorz, P.; Komaromi, I.; Martin, R. L.; Fox, D. J.; Keith, T.; Al-Laham, M. A.; Peng, C. Y.; Nanayakkara, A.; Challacombe, M.; Gill, P. M. W.; Johnson, B.; Chen, W.; Wong, M. W.; Gonzalez, C.; Pople, J. A. 2004.

24. Avogadro software available at http://avogadro.openmolecules.net.

25. Jeffrey, J. G.; Johnson, B. F. G.; Lewis, J.; Raithby, P. R.; Welch, D. A. J. Chem. Soc., Chem. Commun. 1986, 4, 318.

26. Wang, W.; Batchelor, R. J.; Einstein, F. W. B.; Lu, C. Y.; Pomeroy, R. K. Organometallics 1993, 12, 3598.

27. Fowe, E. P.; Belser, P.; Daula, C.; Chermette, H. Phys. Chem. Chem. Phys. 2005, 7, 1732.

28. Beck, W.; Klapoetke, T. M.; Ponikwar, W. Z. Naturforsch. 2002, $57 b, 1120$.

29. Koch, W.; Holthausen, M. C. A Chemist's Guide to Density Functional Theory, 2nd ed.; Wiley-VCH: Weinheim, 2001. 